\title{
STRATEGI PENGEMBANGAN BISNIS TANAMAN HIAS PT MONFORI NUSANTARA DENGAN PENDEKATAN MODEL BISNIS KANVAS
}

\author{
ORNAMENTAL PLANT BUSINESS DEVELOPMENT STRATEGY FOR PT MONFORI NUSANTARA USING \\ BUSINESS MODEL CANVAS APROACH
}

\author{
Tiara Sartika Andryana*)1, Heny K. Daryanto*), dan Agus Maulana**) \\ *) Sekolah Bisnis, Institut Pertanian Bogor \\ Jl. Raya Pajajaran, Bogor 16151 \\ ${ }^{*}$ Universitas Dr Sutomo \\ Jl. Semolowaru No.84, Surabaya 60118
}

\begin{abstract}
The objectives of this study are (1) identifying the business model that is run by PT. Monfori Nusantara with the Canvas Business Model approach; (2) identifying any external and internal factors that affect the business model of the company PT. Monfori Nusantara through SWOT analysis so that alternative strategies are created; (3) Designing a Business Model Canvas repairs as a business development strategy for PT. Monfori Nusantara in the future. The method used was the Canvas Business Model and SWOT. The results of this study are the creation of new values through 9 elements of the Canvas Business Model and strategies such as: expanding the customer segment within the scope of the firm value proposition, increasing efficiency and production capacity, expanding supply propositions, increasing RnD and cost allocation. SWOT analysis on strengths for customer segment elements shows that value propositions and marketing channels have a strong quality relationship with customer segments and products; while the weakness of the customer segment is that the company has not optimized domestic marketing. For the opportunity, the company can utilize the market for plantation crops whereas for the threat, the potential customers can feel bored. PT Monfori Canvas Business Model Improvement produces several targets and developments in each element. The goal of improving each element in the canvas business model aims to expand the potential value propositions that can be offered by PT Monfori.
\end{abstract}

Keywords: business model canvas, floriculture, SWOT, value innovation, tissue culture

\begin{abstract}
Abstrak: Tujuan penelitian ini adalah (1) Mengidentifikasi model bisnis yang dijalankan PT. Monfori Nusantara dengan pendekatan Model Bisnis Kanvas; (2) Mengidentifikasi apa saja faktor eksternal dan internal yang memengaruhi model bisnis perusahaan PT. Monfori Nusantara melalui analisis SWOT sehingga terciptanya alternatif strategi; (3) Merancang Model Bisnis Kanvas perbaikan sebagai strategi pengembangan bisnis PT. Monfori Nusantara di masa depan. Metode yang digunakan adalah Model Bisnis Kanvas dan SWOT. Hasil penelitian ini adalah penciptaan nilai baru melalui 9 elemen Model Bisnis Kanvas dan strategi seperti: memperluas segmen pelanggan dalam lingkup proposisi nilai perusahaan, meningkatkan efisiensi dan kapasitas produksi, memperluas penawaran poposisi, meningkatkan $\mathrm{RnD}$ dan alokasi biaya. Analisis SWOT kekuatan untuk elemen segmen pelanggan, proposisi nilai, saluran pemasaran memiliki kualitas hubungan yang kuat dengan segmen pelanggan maupun produk; sedangkan kelemahan segmen pelanggan: belum mengoptimalkan pemasaran domestik; peluang: memanfaatkan pasar tanaman perkebunan; ancaman: calon pelanggan dapat merasa jenuh. Perbaikan Model Bisnis Kanvas PT Monfori menghasilkan beberapa sasaran dan pengembangan pada tiap elemen. Sasaran pada perbaikan tiap elemen pada model bisnis kanvas bertujuan untuk memperluas potensi proposisi nilai yang dapat ditawarkan PT Monfori.
\end{abstract}

Kata kunci: model bisnis kanvas, florikultura, SWOT, inovasi nilai, kultur jaringan

\footnotetext{
${ }^{1}$ Corresponding author:

Email: andryana.tiara@gmail.com
} 


\section{PENDAHULUAN}

Produk florikultura merupakan produk yang membutuhkan investasi besar, teknologi tinggi dan kebutuhan manajemen yang lebih strategis dibandingkan dengan produk holtikultura lainnya. Oleh sebab itu, keuntungan produk florikultura per unit area lebih tinggi daripada produk agrikultur lain. Saat ini Belanda, Amerika dan Jepang adalah pemimpin produsen dan pasar terbesar untuk produk florikultura di dunia. Produksi global produk florikultur akan terus berkembang, terutama di negara-negara penghasil baru di Asia, Afrika dan Amerika Latin, dan produktivitas di negara-negara ini diperkirakan akan naik lebih tinggi (Xia et al. 2006). Hal ini dikarenakan permintaan dunia akan produk florikultura yang terus meningkat. Tujuh negara mengekspor $72,5 \%$ dari produk florikultur dunia: Belanda (50\%), Columbia (7,5\%), Italia (3\%), Belgia (3\%), Denmark (3\%), Amerika Serikat (3\%), dan Ekuador (3\%) (BCMAFF, 2003).

Daya saing produk florikultura Indonesia masih tergolong rendah bila dibandingkan dengan produk serupa dari negara maju. Nilai ekspor komoditas florikultura pada tahun 2012 sekitar US\$19 juta, menempati urutan ke 51 dunia. Nilai ekspor komoditas florikultura pada tahun 2016 baru sekitar US\$18 juta, mengalami penurunan dari tahun sebelumnya sebesar US\$23 juta, sedangkan nilai impor tanaman hias sebesar US\$13 juta. Perkembangan volume ekspor tanaman hias Indonesia dari tahun 2012-2015 mengalami peningkatan rata-rata $7,95 \%$ per tahun (Direktorat Jendral Holtikultura, 2016). Demikian pula PDB subsektor florikultura mencapai Rp9 Triliun atau sekitar 0,01 bagian dari total nilai perdagangan tanaman hias di dunia yang mencapai US\$60 Miliar. Dengan potensi sumber daya alam yang demikian besar, mestinya Indonesia dapat menduduki peringkat negara produsen florikultura yang terbesar di dunia. Masih diperlukan upaya peningkatan daya saing melalui berbagai cara, diantaranya dengan aplikasi inovasi (BPS, 2012).
Produksi tanaman hias di Indonesia masih sangat rendah dibanding dengan kebutuhan pasar domestik, terlebih untuk pasar ekspor. Selama 5 tahun terakhir, rata-rata peningkatan produksi florikultura dalam bentuk bunga potong naik $7,85 \%$ per tahun, daun potong naik 19,44\% per tahun, tanaman pot pohon naik 5,13\% per tahun, tanaman lansekap 6,85\% per tahun, kelompok tanaman flori tabur juga naik ratarata $6,46 \%$ per tahun (Direktorat Jendral Holtikultura, 2016). Produksi tanaman hias Indonesia selama tahun 2011-2016 dapat dilihat pada Tabel 1. Negara tujuan ekspor tanaman hias tahun 2004 adalah Jepang, Taiwan, Singapura, Vietnam, USA, Kanada, Inggris, Belanda, Perancis, Jerman, dan Denmark. Negara tujuan ekspor tahun 2005 adalah Jepang, Taiwan, Singapura, Kanada, serta Belanda. Negara tujuan ekspor tahun 2006 adalah Jepang, Hongkong, Taiwan, Singapura, Uni Emirat Arab, dan Kanada. Posisi Indonesia di pasar tanaman hias global belum begitu menggembirakan. Indonesia belum tercantum sebagai negara eksportir untuk pasar Uni Eropa yang merupakan pengimpor utama untuk tanaman hias/bunga/daun potong. Indonesia masih tertinggal jauh dari negara Thailand yang merupakan supplier terbesar untuk anggrek (Mattjik, 2011).

Salah satu inovasi yang telah berkembang dalam meningkatkan produktivitas dan daya saing florikultura nasional adalah dengan aplikasi bioteknologi khususnya kultur jaringan. Kultur jaringan merupakan metode perbanyakan tanaman yang dapat menghasilkan bibit tanaman dalam jumlah banyak, waktu yang lebih cepat, bebas virus dan karakteristik yang sama dengan indukan. Teknologi kultur jaringan tanaman telah banyak digunakan untuk penggandaan tanaman berskala besar. Dalam beberapa tahun terakhir, teknik kultur jaringan tanaman telah menjadi kepentingan industri dan memiliki potensi besar untuk menghasilkan tanaman dengan kualitas terbaik, mengisolasi varian yang berguna dalam genotipe hasil panen yang beradaptasi dengan baik dengan ketahanan terhadap penyakit dan kapasitas toleransi stres yang lebih baik (Hussain et al. 2012).

Tabel 1. Produksi tanaman hias Indonesia tahun $2011-2016$

\begin{tabular}{lcccccc}
\hline Kelompok Tanaman & 2011 & 2012 & 2013 & 2014 & 2015 & 2016 \\
\hline Tanaman hias potong (satuan 1000 tangkai) & 486.851 & 616.858 & 684.097 & 740.892 & 785.166 & 763.141 \\
Tanaman hias pot (satuan 1000 pohon) & 26.214 & 24.584 & 29.343 & 38.699 & 34.581 & 31.567 \\
Tanaman hias tabur (satuan 1000 kg) & 22.541 & 22.862 & 30.258 & 36.161 & 31.582 & 31.183 \\
Lanskap (satuan 1000 pohon) & 3.197 & 2.728 & 2.717 & 3.432 & 2.919 & 1.525 \\
\hline
\end{tabular}

Sumber: Direktorat Jendral Hortikultura (2017) 
PT. Monfori Nusantara merupakan salah satu leader perusahaan produsen bibit tanaman hias untuk pasar ekspor. Sebagai salah satu produsen besar penyedia jasa perbanyakan tanaman hias dengan teknik kultur jaringan, PT. Monfori Nusantara memenuhi kebutuhan klien ekspor seperti nursery besar untuk negara Australia, Amerika, Belanda, New Zealand dan Jepang; sedangkan untuk domestik PT. Monfori menjadi supplier ke nursery dan agrowisata seperti Wisata Agro Inkarla, WKF (Wahana Kharisma Flora), PDMA, BUF (Bina Usaha Flora) dan kebun perseorangan. Wilayah cakupan PT. Monfori meliputi wilayah Jawa (Semarang, Jogja, Jawa Barat, Jawa Timur), Manado, Sulawesi dan Papua. Dengan kapasitas produksi yang dapat memenuhi hingga 12.000 .000 bibit per tahun dan beragam varietas tanaman hias, menjadikan PT. Monfori sustain dengan permintaan bibit yang stabil tahun demi tahun.

Permintaan tanaman hias di kota-kota besar semakin besar sehingga potensi bisnis tanaman hias berkembang tiap tahunnya (Sutedi, 2011). Dalam menghadapi persaingan domestik PT. Monfori belum mampu memaksimalkan pasar dikarenakan masalah sulitnya membaca tren pasar yang berubah-ubah, peraturan pemerintah yang tidak berpihak pada pelaku usaha tanaman hias, daya saing industri yang belum berkembang, daya beli masyarakat yang rendah dan berbagai macam aspek lainnya. Dalam menghadapi perubahan lingkungan eksternal maupun internal PT. Monfori membutuhkan pemetaan model bisnis yang dapat memberikan terobosan inovasi untuk pengembangan bisnis perusahaan khususnya untuk pasar domestik.

Sebuah model bisnis dari perusahaan dapat dilihat sebagai sesuatu yang penting dari bermulanya inovasi, dan memiliki potensi untuk mengubah struktur industri yang sudah ada (Markides dan Charitou, 2004). Pendekatan dengan model bisnis dapat dilakukan secara luas baik untuk perusahaan baru, perusahaan yang telah berjalan, nirlaba dan organisasi non-profit (Gavrilova et al. 2014) serta penasihat bisnis (Leschke, 2013).Salah satunya adalah Model Bisnis Kanvas yaitu sebuah bisnis model yang mampu menjelaskan bagaimana organisasi atau perusahaan menangkap nilai, menciptakan dan menyerahkannya kepada konsumen. Model Bisnis Kanvas juga digunakan sebagai bahasa yang dapat dipahami bersama dan meungkinkan untuk membuat inovasi terhadap model bisnis yang telah ada (Osterwalder dan Pigneur, 2015). Dengan melakukan pemetaan menggunakan Model Bisnis Kanvas maka menjadi alat dalam menciptakan nilai baru, mengetahui kondisi bisnis perusahaan dan menciptakan alternatif strategi yang dapat menjadi acuan untuk memperluas peluang pasar dan ikut serta dalam meningkatkan daya saing industri florikultura di Indonesia.

Penelitian tentang pengembangan strategi bisnis telah banyak dilakukan pada industri tanaman hias, seperti yang dilakukan Indra (2017) pada CV. Green Saujana Nursery dengan menggunakan BMC dan SWOT; Ernies (2011) pada prioritas strategi peningkatan penggunaan teknik produksi pada PT Saung Mirwan dengan menggunakan analisis SWOT; Wisanggara et al. (2018) dalam hasil analisis rantai nilai pada PT PDMA; Kurniaty et al. (2012) dalam aktivitas rantai nilai PT Benar Flora dengan menggunakan SWOT dan pendekatan rantai nilai untuk peningkatan daya saing. Inovasi model bisnis sangat penting dalam perencanaan dalam strategi perusahaan untuk menghadapi kondisi lingkungan yang kompleks dan cepat berubah, sehingga menuntut para pemimpin perusahaan untuk cepat memahami kapan model bisnis harus beradaptasi dan bagaimana melaksanakan perubahannya (Agostini, 2014).

Tujuan penelitian ini adalah (1) mengidentifikasi model bisnis yang dijalankan PT. Monfori Nusantara dengan pendekatan Model Bisnis Kanvas; (2) mengidentifikasi apa saja faktor eksternal dan internal yang memengaruhi model bisnis perusahaan PT. Monfori Nusantara melalui analisis SWOT sehingga terciptanya alternatif strategi; (3) merancang model bisnis kanvas perbaikan sebagai strategi pengembangan bisnis PT. Monfori Nusantara di masa depan.

Ruang lingkup penelitian ini membahas mengenai pengembangan bisnis model bisnis tanaman hias di PT. Monfori Nusantara dengan menggunakan pendekatan Model Bisnis Kanvas dan analisis SWOT. Ada beberapa aspek yang akan di analisis, yaitu merumuskan model bisnis PT. Monfori saat ini, aspek internal, eksternal, kekuatan, kelemahan, ancaman, dan peluang dari bisnis model serta merancang strategi perbaikan menggunakan Bisnis Model Kanvas. Penelitian ini terbatas pada tahap penyusunan alternatif strategi untuk pengembangan bisnis tanaman hias di PT. Monfori Nusantara. 


\section{METODE PENELITIAN}

Penelitian dilakukan di PT. Monfori Nusantara, ParungBogor. Kegiatan penelitian dilakukan selama 4 bulan pada September 2017 hingga Desember 2017 dengan pemilihan lokasi secara purposive dengan pertimbangan perusahaan merupakan salah satu perusahaan besar berskala internasional di bidang jasa perbanyakan tanaman hias dengan teknik kultur jaringan yang memiliki permintaan ekspor maupun domestik yang kontinu.

Jenis Data yang digunakan dalam penelitian ini terdiri dari data primer dan sekunder. Data primer diperoleh melalui in-depth interview, FGD dan pengisian kuesioner kepada responden internal perusahaan maupun eksternal perusahaan. Data sekunder diperoleh melalui dokumen perusahaan, website, dan studi literatur. Pengolahan dan analisis data dilakukan dalam bentuk deskriptif kualitatif. Jenis dan sumber data dapat dilihat pada Tabel 2.

Pemilihan responden dilakukan secara purposive sampling, yaitu responden yang memiliki wawasan dan informasi mengenai data yang ingin diperoleh. Responden terdari dari responden internal dan eksternal. Responden internal pada penelitian ini adalah pemilik perusahaan, general manager, manager produksi, manager pemasaran, supervisor produksi, kepala $\mathrm{RnD}$, manager keuangan dan manager legal. Responden eksternal adalah Bapak Mohammad Baidowi dari anggota ASBINDO (Asosiasi Bunga Indonesia), Bapak
Dr. Sarwo Edhy (Direktur Buah dan Florikultura), dan Ibu Ir. Farida Nuraini (Kepala Seksi Pengembangan Kawasan Hortikultura).

Dalam mencapai tujuan penelitian, penulis menggunakan alat analisis Model Bisnis Kanvas dan analisis SWOT. Pendekatan menggunakan model bisnis dapat menjadi alat yang efektif untuk menilai potensi bisnis sebelum rencana bisnis dikembangkan (Gavrilova et al. 2014). Esensi dari model bisnis dalam mendefinisikan cara perusahaan memberikan nilai kepada pelanggan, menarik pelanggan untuk membayar nilai tersebut yang dapat menjadi laba perusahaan (Teece, 2010). Oleh karena itu, konsep ini memiliki nilai praktis yang sangat besar (Magretta, 2002).

Dalam melihat keseluruhan dari komponen model bisnis dan menilai integritasnya adalah dengan mengombinasikan analisis kekuatan, kelemahan, peluang dan ancaman (SWOT) dengan Model Bisnis Kanvas. Hal ini dilakukan untuk meciptakan inovasi dan pembaharuan dalam bisnis. Dalam analisis Model Bisnis Kanvas analisis SWOT terdiri dari analisis internal yang tercakup dalam analisis 9 elemennya yang berupa segmen pelanggan, proposisi nilai, saluran, hubungan dengan pelanggan, arus pendapatan, sumber daya utama, aktivitsa kunci, kemitraan utama, serta struktur biaya perusahaan. Sedangkan faktor eksternal yang dianalisis dalam Model Bisnis Kanvas meliputi kekuatan pasar, kekuatan industri, tren-tren kunci, dan kekuatan ekonomi makro (Osterwalder dan Pigneur, 2015).

Tabel 2. Jenis dan sumber data

Jenis Data
Data Primer
Pemetaan Model Bisnis Kanvas PT. Monfori Nusantara saat
ini

Analisis lingkungan bisnis perusahaan (eksternal) dan internal perusahaan

Pengembangan bisnis PT Monfori

\section{Data Sekunder}

Dokumen perusahaan, website, dan studi pustaka yang meliputi gambaran umum perusahaan, visi misi dan data operasional perusahaan

Sumber Data

General Manager, divisi produksi, divisi RnD, divisi marketing, logistik, divisi keuangan dan tim lain yang terkait

General Manager, divisi produksi, divisi RnD, divisi marketing, logistik, divisi keuangan, pelanggan dan pakar industri florikultura

General Manager, divisi produksi, divisi RnD, divisi marketing, logistik, divisi keuangan dan tim lain yang terkait

Laporan operasional perusahaan 2015-2017, divisi marketing, divisi produksi, HRD dan General Manager 
Penelitian ini diawali dengan adanya permasalahan yang dihadapi PT Monfori sehingga membutuhkan strategi yang tepat dalam rangka pengembangan bisnis perusahaan. Selanjutnya dengan pendekatan model bisnis, melakukan pemetaan model bisnis PT. Monfori dengan menganalisis profil dan aktivitas bisnis internal perusahaan pada sembilan unsur Model Bisnis Kanvas. Tahap selanjutnya adalah menganalisis setiap unsur Model Bisnis Kanvas menggunakan SWOT untuk mengidentifikasi faktor-faktor internal maupun ekstenal yang memperngaruhi lingkungan bisnis PT Monfori. Melalui hasil analisis SWOT tersebut dapat diketahui isu-isu strategik penting dalam pelaksanaan model bisnis perusahaan saat ini. Selanjutnya dilakukan penyususnan strategi perbaikan terhadap 9 elemen pada Model Bisnis Kanvas perbaikan. Setelah Model Bisnis Kanvas perbaikan sudah terbentuk, maka dilakukan perumusan implikasi manajerial sebagai pilihan keputusan bagi perusahaan. Kerangka pemikiran konseptual penelitian dapat dilihat pada Gambar 1.

\section{HASIL}

\section{Identifikasi Model Bisnis Kanvas PT. Monfori Nusantara Saat ini}

Esensi dari model bisnis dalam mendefinisikan cara perusahaan memberikan nilai kepada pelanggan, menarik pelanggan untuk membayar nilai tersebut yang dapat menjadi laba perusahaan (Teece, 2010). Hasil identifikasi meta-model dari Model Bisnis Kanvas PT. Monfori Nusantara saat penelitian berlangsung dilakukan melalui interview mendalam dengan responden internal dari berbagai divisi manajerial. Keterkaitan antar kesembilan elemen tersebut memberikan penjelasan dan gambaran model bisnis perusahaan PT Monfori saat ini. Pemetaan model bisnis kanvas saat ini dapat dilihat pada Gambar 2.

\section{Customer Segment}

Dalam memenuhi segmen pelanggan pasar ceruk yang memiliki kebutuhan spesifik, PT. Monfori memiliki konsumen pasar ekspor yang terdiri wholesale nursery, breeder (pemulia tanaman) ekspor, distributor nursery dan perusahaan yang bergerak di bidang jasa lanskap; dan konsumen pasar domestik yang terdiri dari nursery lokal, perkebunan milik perseorangan, florist, agrowisata dan proyek lanskap.

\section{Value Proposition}

Nilai yang ditawarkan PT Monfori kepada pelanggannya merupakan jenis kustomisasi. Nilai proposisi yang ditawarkan oleh PT Monfori adalah (1) Good Quality Product, (2) Produk bersih dari penyakit dan bakteri, (3) Citra Perusahaan dan kredibilitas dalam membangun kepercayaan pelanggan, dan (4) Teknologi canggih dan fasilitas yang mendukung aktivitas produksi yang lengkap.

\section{Channels}

Dalam menyampaikan penawaran produk dan jasa, PT. Monfori menggunakan pemasaran melalui saluran langsung yaitu hubungan face-to-face dengan pelanggan maupun komunikasi melalui email dan telepon dan media komunikasi lainnya. Selain itu perusahaan menggunakan pemasaran saluran tidak langsung seperti penawaran produk dan jasa melalui website yang berisikan produk tanaman hias dan pelayanan jasa, selain itu PT. Monfori aktif dalam kegiatan promosi melalui pameran dalam negeri dan aktif sebagai anggota ASBINDO (Asosiasi Bunga Indonesia).

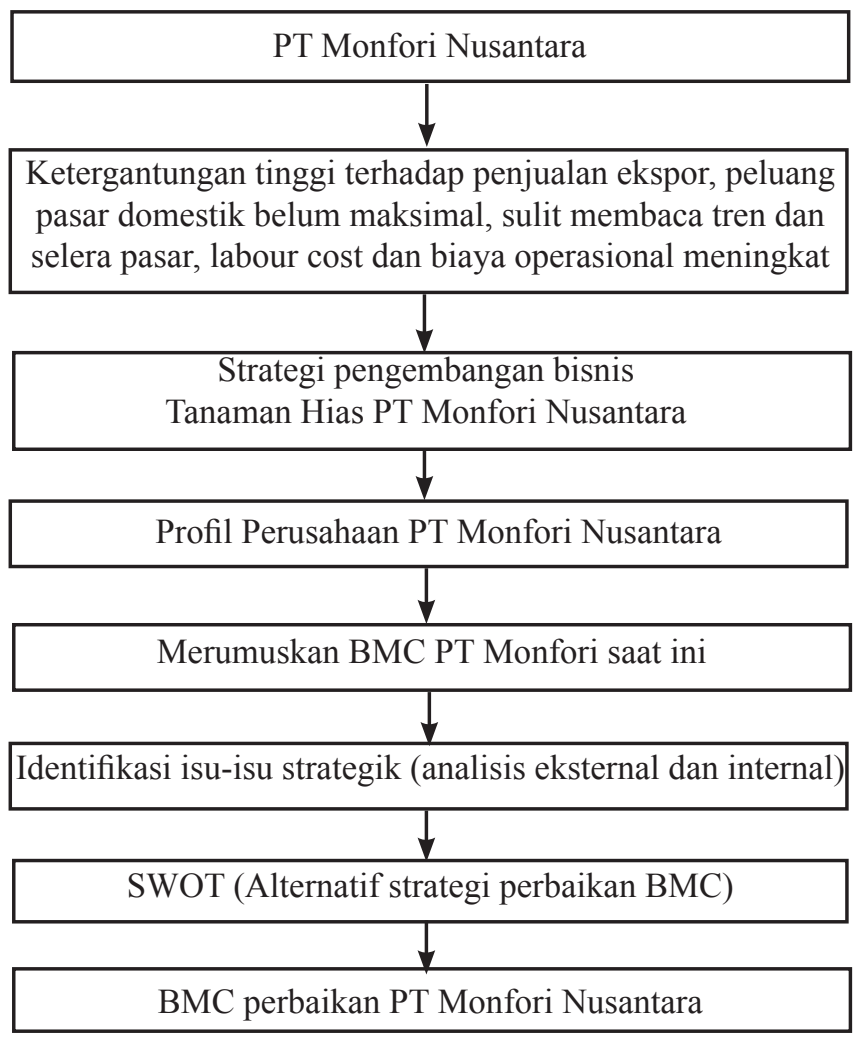

Gambar 1. Kerangka pemikiran penelitian 


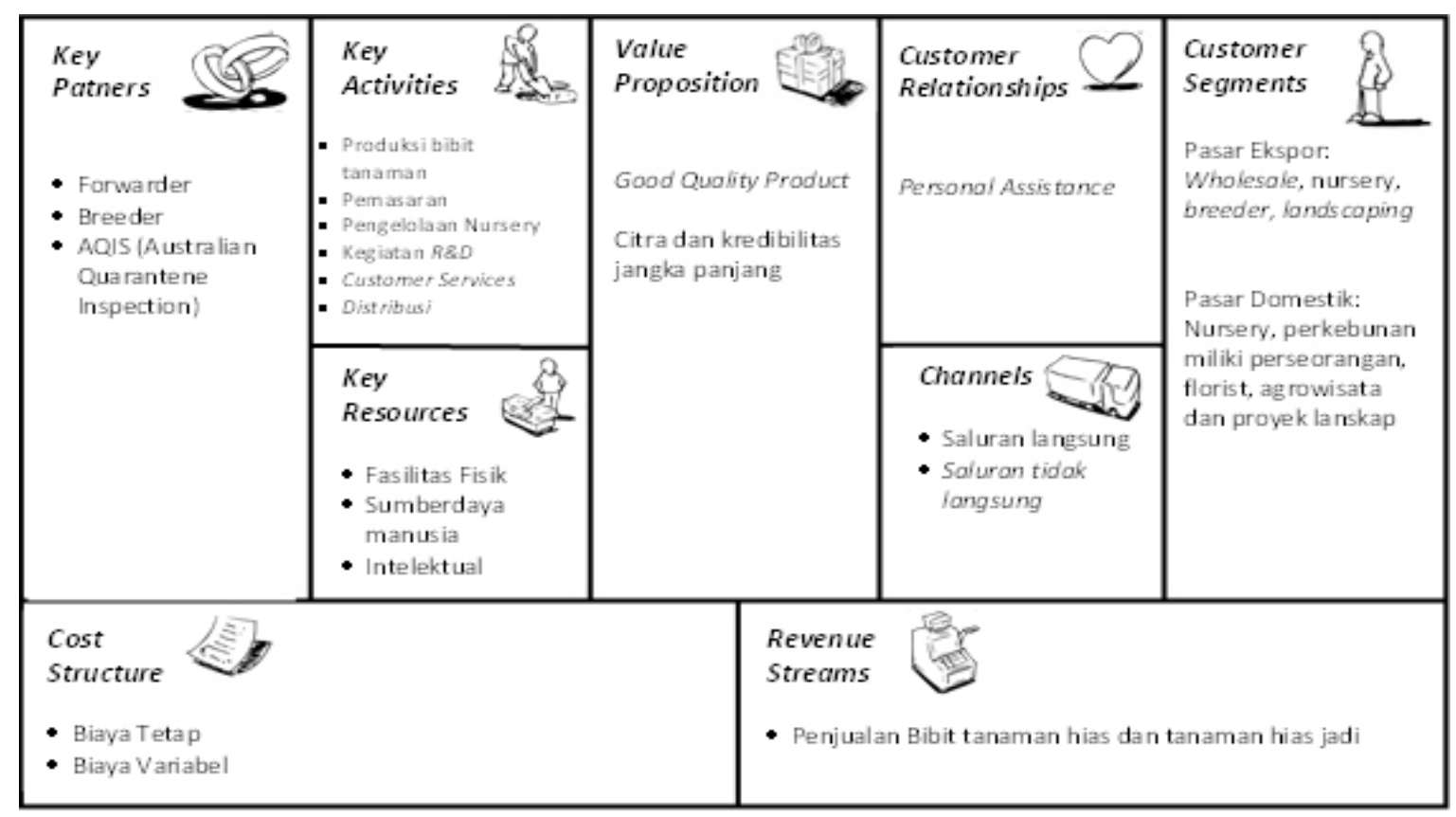

Gambar 2 Model bisnis kanvas PT Monfori Nusantara saat ini

\section{Customer Relationship}

PT Monfori membangun hubungan dengan pelanggan dengan pendekatan personal assistant melalui sarana email, telepon dan whatsapp untuk follow-up informasi mengenai jadwal produksi dan pesanan yang tersedia sesuai kontrak tahunan dari kesepakatan dengan pelanggan. Selain itu hubungan pelanggan yang dibangun PT. Monfori berupa penanganan produk pasca pengiriman kepada pelanggan sehingga tanaman dapat tumbuh dengan baik di nursery pelanggan.

\section{Revenue Stream}

Sumber arus pendapatan PT. Monfori berasal dari jasa perbanyakan bibit tanaman hias dan penjualan tanaman hias jadi. Sumber pendapatan untuk pelanggan ekspor adalah pendapatan berulang.

\section{Key Resources}

Sumber daya kunci PT. Monfori terdiri atas fasilitas fisik seperti bangunan kantor, fasilitas kantor, lab produksi, nursery, mesin lab, dan mobil; Sumber daya manusia seperti operator produksi, operator R\&D, tim media kultur jaringan, tim marketing, divisi legal, divisi keuangan, divisi nursery, manager, staff QC, HRD, direktur dan lainnya; Intelektual, yaitu perusahaan yang memiliki pengalaman matang terhadap teknologi kultur jaringan dengan tim yang berpengalaman dan ahli dalam bidang tersebut.

\section{Key Activities}

Aktivitas kunci dalam penyampaian nilai perusahaan adalah Produksi bibit dengan kultur jaringan; Pemasaran bibit dan tanaman hias untuk pasar ekspor maupun domestik, kegiatan pameran dalam maupun luar negeri dan pemasaran melalui website; Pengelolaan nursery untuk aklimatisasi bibit tanaman dan maintenance tanaman hias; Kegiatan R\&D, yaitu proses inisiasi tanaman induk dan pemuliaan tanaman varietas baru; dan Customer Services yang dilakukan dari tahap pemesanan produk hingga pasca produk sampai pada pelanggan.

\section{Key partnership}

Mitra-mitra yang dimiliki PT Monfori dalam membantu kegiatan model bisnis perusahaan adalah Breeder (pemulia tanaman) luar negeri sebagai pemasok tanaman hias berlisensi; dan forwarder (Shipping agent/ carrier). Jenis hubungan kemitraan perusahaan menurut teori Osterwalder dan Pigneur (2015) termasuk dalam hubungan pembeli dan pemasok untuk menjamin pasokan yang dapat diandalkan.

\section{Cost Structure (Struktur Biaya)}

Struktur biaya PT. Monfori terdiri atas biaya variabel dan biaya tetap. Untuk biaya variabel terdiri atas gaji karyawan; biayalistrik; consumables; dan supplies. Biaya variabel terdiri atas license and permit; Maintenance, Profesional fee, Freight; dan Packing. 


\section{Analisis SWOT Model Bisnis Kanvas PT Monfori Nusantara}

Setelah melakukan identifikasi dan pemetaan sembilan elemen kunci model bisnis kanvas PT Monfori Nusantara selanjutnya dilakukan analisis SWOT pada setiap elemen yang ada. Dinamika lingkungan eksternal dan internal organisasi memengaruhi model bisnis perusahaan. Namun, organisasi menggunakan strategi bisnis untuk menanggapi perubahan lingkungan makro maupun mikro. Hasil analisis SWOT bisnis model kanvas PT Monfori Nusantara dapat dilihat pada Tabel 3.

Tabel 3. Analisis SWOT PT. Monfori Nusantara

\begin{tabular}{|c|c|c|c|c|}
\hline Elemen & Kekuatan & Kelemahan & Peluang & Ancaman \\
\hline $\begin{array}{l}\text { Customer } \\
\text { Segments }\end{array}$ & $\begin{array}{l}\text { Kualitas hubungan } \\
\text { sesuai dengan segmen } \\
\text { pelanggan }\end{array}$ & $\begin{array}{l}\text { Belum } \\
\text { mengoptimalkan } \\
\text { pemasaran pada pasar } \\
\text { domestik }\end{array}$ & $\begin{array}{l}\text { Memanfaatkan } \\
\text { pasar permintaan } \\
\text { tanaman perkebunan } \\
\text { untuk meningkatkan } \\
\text { keuntungan }\end{array}$ & $\begin{array}{l}\text { Calon pelanggan } \\
\text { dapat merasa jenuh } \\
\text { jika perusahaan tidak } \\
\text { meningkatkan inovasi } \\
\text { nilai. }\end{array}$ \\
\hline $\begin{array}{l}\text { Value } \\
\text { Proposition }\end{array}$ & $\begin{array}{l}\text { Sinergi yang kuat } \\
\text { antara produk dengan } \\
\text { layanan jasa }\end{array}$ & $\begin{array}{l}\text { Proposisi belum } \\
\text { memiliki dampak } \\
\text { yang kuat bagi } \\
\text { kebutuhan pelanggan } \\
\text { domestik }\end{array}$ & $\begin{array}{l}\text { PT Monfori dapat } \\
\text { memperluas, melengkapi } \\
\text { atau menambah produk } \\
\text { untuk meningkatkan } \\
\text { proposisi nilainya dimata } \\
\text { konsumen. }\end{array}$ & $\begin{array}{l}\text { Perbandingan harga } \\
\text { produk non-kultur } \\
\text { jaringan dan produk } \\
\text { kultur jaringan. }\end{array}$ \\
\hline Channels & $\begin{array}{l}\text { Saluran sudah sesuai } \\
\text { dengan segmen } \\
\text { pelanggan. }\end{array}$ & $\begin{array}{l}\text { Pasar domestik PT } \\
\text { Monfori kurang } \\
\text { memiliki jangkauan } \\
\text { saluran yang kuat }\end{array}$ & $\begin{array}{l}\text { Dapat menciptakan } \\
\text { saluran baru dengan } \\
\text { memanfaatkan peluang } \\
\text { dari saluran-saluran mitra } \\
\text { perusahaan. }\end{array}$ & $\begin{array}{l}\text { pesaing memiliki akses } \\
\text { terhadap jaringan pasar } \\
\text { dan komunikasi yang } \\
\text { lebih baik. }\end{array}$ \\
\hline $\begin{array}{l}\text { Customer } \\
\text { Relationship }\end{array}$ & $\begin{array}{l}\text { brand yang kuat } \\
\text { sebagai perusahaan } \\
\text { jasa perbanyakan } \\
\text { tanaman hias. }\end{array}$ & $\begin{array}{l}\text { belum memanfaatkan } \\
\text { database pelanggan } \\
\text { secara maksimal untuk } \\
\text { memperluas pasar }\end{array}$ & $\begin{array}{l}\text { Meningkatkan } \\
\text { pelayanannya atas } \\
\text { aduan,masukan/kritikan } \\
\text { dari pelanggan dengan } \\
\text { lebih baik melalui survei } \\
\text { pelanggan }\end{array}$ & $\begin{array}{l}\text { Adanya } \\
\text { misscomunication } \\
\text { dengan pelanggan }\end{array}$ \\
\hline Revenue Streams & $\begin{array}{l}\text { memiliki arus } \\
\text { pendapatan berulang }\end{array}$ & $\begin{array}{l}\text { belum memiliki } \\
\text { pendapatan yang } \\
\text { terdiversivikasi }\end{array}$ & $\begin{array}{l}\text { Dapat menciptakan arus } \\
\text { pendapatan baru dengan } \\
\text { memperluas proposisi } \\
\text { nilai perusahaan }\end{array}$ & $\begin{array}{l}\text { potensi margin dapat } \\
\text { berkurang karena } \\
\text { pengaruh dari teknologi } \\
\text { pesaing. }\end{array}$ \\
\hline Key Resources & $\begin{array}{l}\text { sumberdaya utama } \\
\text { yang kuat }\end{array}$ & R\&D belum optimal & $\begin{array}{l}\text { sumber daya utama di } \\
\text { upgrading-skill }\end{array}$ & $\begin{array}{l}\text { Kapasitas produksi yang } \\
\text { terbatas }\end{array}$ \\
\hline Key Activities & $\begin{array}{l}\text { Aktivitas kunci sulit } \\
\text { ditiru pesaing }\end{array}$ & $\begin{array}{l}\text { nursery masih belum } \\
\text { terorganisir dengan } \\
\text { baik sistem kerjanya }\end{array}$ & $\begin{array}{l}\text { Meningkatkan efisiensi } \\
\text { produksi dengan } \\
\text { investasi pada teknologi } \\
\text { atau new resources }\end{array}$ & $\begin{array}{l}\text { Belum adanya } \\
\text { penetapan target untuk } \\
\text { tim marketing dalam } \\
\text { memperluas prospek } \\
\text { pelanggan }\end{array}$ \\
\hline Key Patnership & $\begin{array}{l}\text { Hubungan kerjasama } \\
\text { dengan mitra-mitra } \\
\text { berjalan dengan baik. }\end{array}$ & $\begin{array}{l}\text { Belum } \\
\text { memaksimalkan peran } \\
\text { mitra-mitra untuk } \\
\text { memperluas proposisi } \\
\text { nilai. }\end{array}$ & $\begin{array}{l}\text { memanfaatkan saluran } \\
\text { mitra-mitra untuk } \\
\text { menjangkau pelanggan } \\
\text { untuk perluasan pasar }\end{array}$ & $\begin{array}{l}\text { Ada kemungkinan } \\
\text { mitra-mitra PT Monfori } \\
\text { bekerja sama dengan } \\
\text { perusahaan pesaing. }\end{array}$ \\
\hline Cost Structure & $\begin{array}{l}\text { Struktur biaya sesuai } \\
\text { dengan model bisnis } \\
\text { yang dijalankan. }\end{array}$ & $\begin{array}{l}\text { promosi dalam negeri } \\
\text { kurang efektif dan } \\
\text { kurang tepat dalam } \\
\text { memperluas pasar } \\
\text { baru. }\end{array}$ & $\begin{array}{l}\text { melakukan efisiensi } \\
\text { dalam aktivitas tertentu } \\
\text { sehingga mengurangi } \\
\text { biaya produksi atau biaya } \\
\text { operasional lainnya. }\end{array}$ & $\begin{array}{l}\text { Jika pesaing mampu } \\
\text { memberikan layanan } \\
\text { jasa/produk dengan } \\
\text { penyelesaian/waktu yang } \\
\text { lebih cepat. }\end{array}$ \\
\hline
\end{tabular}




\section{Perbaikan Model Bisnis Kanvas PT Monfori Nusantara}

Strategi adalah konsep mediasi antara model bisnis perusahaan dan lingkungannya (Mansfield dan Fourie, 2004). Menurut Chesbrough (2010) untuk menjadi sukses dalam inovasi model bisnis, organisasi perlu memiliki visi kepemimpinan yang jelas diarahkan pada inovasi model bisnis. Dalam penciptaan model bisnis yang inovatif menjadikan tantangan bagi perusahaan untuk menghasilkan keunggulan kompetitif (Coles, 2004). Bereksperimen dengan model bisnis akan memiliki sumber daya yang cukup dan akan menaklukkan hambatan dalam organisasi. Ini akan mengarah pada model penemuan-driven (McGrath, 2010).

Berdasarkan hasil analisis SWOT terhadap sembilan elemen Model Bisnis Kanvas dan deep interview dengan pihak internal perusahaan, maka dirancang model bisnis perbaikan yang dapat menjadi strategi dalam meningkatkan daya saing perusahaan dalam industri tanaman hias nasional. Model bisnis sebuah organisasi bisa memberikan wawasan tentang penyelarasan strategi tingkat tinggi dan mendasarinya tindakan dalam sebuah organisasi, yang pada gilirannya mendukung strategi daya saing (Casadesus-Masanell dan Ricart,
2010). Penyajian Model Bisnis Kanvas perbaikan PT Monfori Nusantara dapat dilihat pada Gambar 3.

\section{Customer Segment}

Model bisnis perbaikan pada elemen customer segment terdapat 3 sasaran konsumen untuk pengembangan bisnis perusahaan yaitu: a) Pelanggan untuk komoditas bibit perkebunan, b) Pelanggan ekspor wilayah Asia Tenggara, c) Pelanggan jasa penyewaan tanaman hias. Perluasan sasaran customer segment pada konsumen bibit tanaman perkebunan didasari pada potensi pasar yang besar untuk bibit tanaman perkebunan di pasar domestik dan sudah mulai menggunakan teknik kultur jaringan sehingga perusahaan perlu melihat peluang bisnis melalui permintaan bibit tanaman perkebunan seperti pisang, kopi, sawit dan coklat. Selain itu perusahaan perlu mencari peluang konsumen tanaman hias yang berada di wilayah Asia Tenggara untuk meringankan biaya pengiriman. Berdasarkan wawancara dengan narasumber, prospek Asia Tengara seperti Jepang dan Korea. Sedangkan untuk konsumen jasa penyewaan tanaman hias, hal tersebut berdasarkan perkembangan hotel, kantor, rumah makan, dan rumah sakit yang terus meningkat dan membutuhkan produk tanaman hias sebagai dekorasi penunjang.

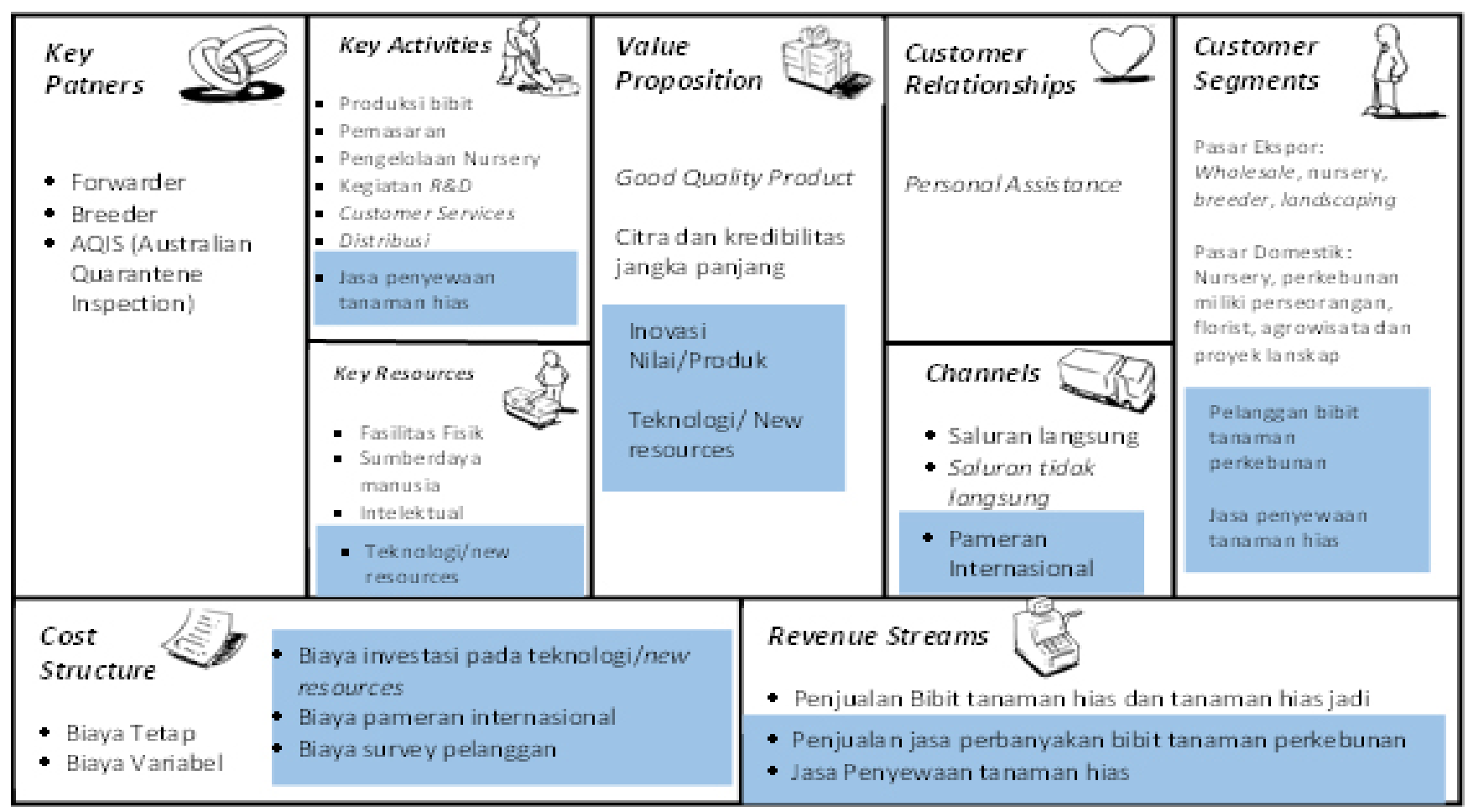

Gambar 3. Model bisnis kanvas perbaikan PT Monfori Nusantara 


\section{Value Propositions}

Model bisnis perbaikan berupa inovasi nilai dapat terwujud melalui kebaharuan komoditas kultur jaringan seperti bibit kultur jaringan tanaman perkebunan, selain itu inovasi nilai dapat berupa efisiensi produksi untuk mencapai pengurangan biaya (cost reduction) dengan mengurangi stok yang disimpan di nursery, selain itu inovasi nilai dapat diterapkan dengan menggunakan sumberdaya yang ada untuk menciptakan produk baru seperti vertical garden. Investasi perusahaan untuk teknologi dan sumberdaya baru dilakukan untuk meningkatkan nilai inovasi atau menurunkan biaya penawaran. Dalam jangka panjang pengembangan bisnis perusahaan dapat meningkatkan daya saing dalam industri jika menginvestasikan pada inovasi nilai dan sumberdaya baru.

\section{Channels}

Model bisnis perbaikan untuk elemen channels adalah aktif dalam mengikuti pameran internasional dan mengupdate website untuk meningkatkan promosi online. Perluasan elemen channels tersebut berdasarkan hasil pengamatan dan wawancara pada bagian manajerial perusahaan mengenai keefektifan promosi melalui pameran dan event dalam negeri yang menunjukan kurang efektif terhadap peningkatan permintaan. Alokasi dana promosi untuk mengikuti pameran dan event dalam negeri disarakan agar dialihkan untuk mengikuti pameran internasional agar lebih efektif dan tepat sasaran.

\section{Customer Relationship}

Model bisnis perbaikan untuk elemen customer relationship adalah melakukan visiting pada pelanggan dan penilaian pelanggan terhadap pelayanan perusahaan melalui survei penilaian kepuasan konsumen.

\section{Revenue Streams}

Dengan adanya perubahan pada inovasi nilai perusahaan berupakomoditastanamanperkebunan; dan peningkatan efisiensi biaya melalui jasa penyewaan tanaman hias maka akan berpengaruh terhadap peningkatan revenue streams perusahaan. Dalam hal ini penambahan customer segment dan value propositions berdampak terhadap peningkatan pendapatan perusahaan.

\section{Key Resources}

Untuk menciptakan nilai, sumber daya dan aktivitas dibutuhkan (Chesbrough dan Rosenbloom, 2002; Weill et al. 2005; Zott et al. 2010). Model bisnis perbaikan untuk elemen key resources adalah meningkatkan kapasitas produksi dan investasi pada teknologi atau new resources. Strategi meningkatkan kapasitas produksi dapat dilakukan dengan bekerja sama dengan pihak lain ataupun menyewa lahan.

\section{Key Activities}

Model bisnis perbaikan untuk elemen key activities adalah jasa penyewaan tanaman hias dan jasa perbanyakan bibit tanaman perkebunan. Strategi jasa penyewaan tanaman hias dilakukan untuk membuka aliran pendapatan baru dengan menggunakan stock tanaman hias di nursery yang belum terjual. Berdasarkan pengamatan di lapang pada jasa penyewaan tanaman, diketahui bahwa semakin meningkat permintaan penyewaan jasa tanaman untuk perkantoran, hotel, rumah sakit dan industri sejenis.

\section{Key Partnership}

Model bisnis dapat diinovasi melalui reorganisasi berbagai jenis proses dan aset, atau dapat diinovasi melalui kerja sama dengan organisasi lain untuk melengkapi layanan atau barang yang model bisnisnya kurang (Zott et al. 2011). Model bisnis perbaikan untuk elemen key partnership adalah bekerjasama dengan breeder ekspor dan research. Strategi bekerjasama dengan breeder ekspor menguntungkan perusahaan dalam memperoleh lisensi tanaman hasil pemuliaan oleh breeder.

\section{Cost Structure}

Model bisnis perbaikan untuk elemen cost structure adalah biaya survei pasar, biaya investasi new resources dan biaya untuk mengoptimalkan promosi online.

\section{Implikasi Manajerial}

Faktor dalam menerapkan model bisnis yang sukses dalam organisasi yang ada, keputusan awal akan memiliki pengaruh besar terhadap keberhasilan pelaksanaan. Namun, penyesuaian dari waktu ke waktu dan evaluasi pengembangan model bisnis sangat penting (Osterwalder et al. 2011). Implikasi 
manajerial merupakan kegiatan perusahaan dalam menyusun strategi pengembangan bisnis perusahaan yang disesuaikan dengan kondisi dan kemampuan perusahaan saat ini.

Beberapa rekomendasi yang dapat menjadi pertimbangan perusahaan adalah (1) Perusahaan dapat melihat potensi yang ada di pasar dengan melayani segmen pasar baru yaitu pelanggan yang membutuhkan bibit tanaman perkebunan. Potensi pasar pada segmen tersebut tinggi dan sudah banyak menggunakan kultur jaringan sebagai perbanyakan. (2) Meningkatkan efisiensi produksi dan biaya dengan mengurangi oversupply bibit tanaman hias (3) Meningkatkan kapasitas produksi. Strategi yang bisa dipertimbangkan adalah dengan menyewa atau bekerjasama dengan lab produksi lain atau mengatur sistem produksi lab agar lebih efektif dan efisien sehingga dapat menambah kapasitas produksi. (4) Memperluas penawaran proposisi nilai perusahaan dalam bidang jasa yaitu penyewaan tanaman hias untuk perkantoran, hotel dan rumah sakit. (5) Meningkatkan kualitas Research and Development (R\&D) perusahaan dengan pelatihan dalam bidang kultur jaringan. (6) Pengalokasian biaya pameran domestik untuk mengikuti pameran di luar negeri. (7) Melakukan kerja sama dengan balai penelitian atau dinas terkait untuk memproduksi benih lokal dan pemuliaan tanaman.

\section{KESIMPULAN DAN SARAN}

\section{Kesimpulan}

Hasil identifikasi Model Bisnis Kanvas PT Monfori Nusantara saat ini diketahui Segmen pelanggan: pelanggan ekspor dan pasar domestik; Nilai proposisi: good quality product, citra perusahaan dan kredibilitas; Saluran pemasaran: saluran langsung dan tidak langsung; hubungan pelanggan perusahaan: pendekatan personal assistant; sumber arus pendapatan: jasa perbanyakan bibit tanaman hias; sumber daya kunci: fasilitas fisik, sumber daya manusia, intelektual. Aktivitas kunci perusahaan adalah: produksi bibit, pemasaran, pengelolaan nursery, $\mathrm{R} \& \mathrm{D}$, dan customer services; Mitra perusahaan: breeder dan forwarder; dan Struktur biaya PT. Monfori terdiri atas: biaya variabel dan biaya tetap.
Analisis SWOT kekuatan untuk elemen segmen pelanggan, proposisi nilai, saluran pemasaran memiliki kualitas hubungan yang kuat dengan segmen pelanggan maupun produk; sedangkan kelemahan segmen pelanggan: belum mengoptimalkan pemasaran domestik; peluang: memanfaatkan pasar tanaman perkebunan; ancaman: calon pelanggan dapat merasa jenuh. Kelemahan proposisi nilai proposisi belum memiliki dampak yang kuat; peluang: memperluas, melengkapi atau menambah produk; ancaman perbandingan harga produk non-kultur jaringan dan produk kultur jaringan. Kelemahan saluran pemasaran: pasar kurang memiliki jangkauan yang kuat; peluang: menciptakan saluran baru; serta ancaman: pesaing memiliki akses terhadap jaringan pasar. Hubungan pelanggan terdapat kekuatan: brand yang kuat; kelemahan: belum memanfaatkan database pelanggan secara maksimal; peluang: meningkatkan pelayanan; sertaancaman: adanyamisscomunication. Kekuatan dari arus pendapatan: memiliki arus pendapatan berulang; kelemahan: pendapatan belum terdiversifikasi; peluang: menciptakan arus pendapatan baru; ancaman: potensi margin dapat berkurang karena pengaruh dari teknologi pesaing. Kekuatan pada sumber daya kunci: sumberdaya utama yang kuat; kelemahan: R\&D belum optimal; peluang: upgrading skill; ancaman: kapasitas produksi yang terbatas. Kekuatan aktivitas kunci: aktivitas kunci sulit ditiru pesaing; kelemahan: nursery masih belum terorganisir dengan baik; peluang: meningkatkan efisiensi produksi; ancaman: belum adanya target marketing. Kekuatan pada mitra kunci: hubungan kerjasama yang baik; kelemahan: peran mitra belum maksimal; peluang: memanfaatkan saluran mitra untuk menjangkau pasar baru; ancaman: ada kemungkinan mitra bekerjasama dengan pesaing. Kekuatan untuk struktur biaya: struktur biaya sesuai dengan model bisnis; kelemahan: promosi dalam negeri kurang efektif; peluang: melakukan efisiensi dalam aktivitas; ancaman: jika pesaing mampu memberikan layanan jasa/produk dengan penyelesaian/waktu yang lebih cepat.

Perbaikan Model Bisnis Kanvas PT Monfori menghasilkan beberapa sasaran dan pengembangan pada tiap elemen meliputi: 1) Perluasan segmen pelanggan bibit tanaman perkebunan, pelanggan ekspor untuk Asia Tenggara, dan jasa penyewaan tanaman hias; 2) inovasi nilai dan teknologi/new resources; 3 ) Aktif mengikuti pameran internasional dan mengupdate website; 4) Melakukan visiting pelanggan dan survei penilaian kepuasan konsumen; 5) Meningkatkan 
kapasitas produksi dan investasi pada teknologi atau new resources; 7) Pelayanan jasa penyewaan tanaman hias dan jasa perbanyakan bibit tanaman perkebunan; 8) Bekerja sama dengan breeder ekspor dan research. Sasaran pada perbaikan tiap elemen pada model bisnis kanvas bertujuan memperluas potensi proposisi nilai yang dapat ditawarkan PT Monfori.

\section{Saran}

PT Monfori Nusantara dapat mengkoordinasikan jajaran manejemen dan direksinya untuk mengimplementasikan strategi pengembangan bisnis baru berdasarkan model bisnis kanvas perbaikan yang telah disusun dalam penelitian ini, serta mengevaluasi hasil terhadap penerapan strategi model bisnis baru tersebut. Penelitian lebih lanjut dapat dilakukan evaluasi terhadap implementasi model bisnis perbaikan untuk menilai strategi dan menyempurnakan penelitian ini.

\section{DAFTAR PUSTAKA}

Agostini A. 2014. Differences in business model innovation, a challenges perspective [disertasi]. Halmstad: Halmstad University College.

[BPS] Badan Pusat Statistik. 2012. Neraca EksporImpor. Badan Pusat Statistis Indonesia. https:// www.bps.go.id/subject/8/ekspor-impor.html [2017 November 5].

[BCMAFF] British Colombia Ministry of Agriculture, Food and Fisheries. 2003. An overview of the BC floriculture industry. BCMAL Fact Sheets and Publications. 1-13.

Casadesus-Masanell R, Ricart JE. 2010. From strategy to business models and onto tactics. Long range planning 43(2-3): 195-215. https://doi. org/10.1016/j.lrp.2010.01.004.

Chesbrough H. 2010. Business model innovation: opportunities and barriers. Long Range Planning 43(2):354-363.https://doi.org/10.1016/j. lrp.2009.07.010.

Chesbrough HW, Rosenbloom RS. 2002. The Role Of The Business Model In Capturing Value From Innovation: Evidence from Xerox Corporation's technology spin-off companies. Industrial and Corporate Change 11: 529- 555. https://doi. org/10.1093/icc/11.3.529.

Coles C. 2004. Business model innovation breakthrough moves. The Journal of Business Strategy 25(1): 16 - 26. https://doi. org/10.1108/02756660410515976.

Direktorat Jenderal Hortikultura. 2016. Revisi Rencana Strategis Direktorat Jenderal Hortikultura 2015-2019.http://pertanian.go.id/file/ RENSTRA_2015-2019.pdf [2017 September 4].

Ernies. 2011. Strategi pengembangan teknologi dan inovasi usaha tanaman hias di PT. Saung Mirwan [tesis]. Bogor: Sekolah Pascasarjana, Institut Pertanian Bogor.

Gavrilova T, Alsufyev A, Yanson AS. 2014. Modern national of business model visua tren. Journal Foursight-Russia 8(2): 56-70.

Hussain A, Qarshi IA, Nazir H, Ullah I. 2012. Plant tissue culture: current status and opportunities. In Recent advances in plant in vitro culture. InTechOpen.https://www.intechopen.com/ books/recent-advances-in-plant-in-vitroculture/plant-tissue-culture-current-status-andopportunities. [2017 September 4].

Indra ZF. 2017. Strategi Pengembangan Bisnis Tanaman Hias CV. Green Saujana Nursery [tesis]. Bogor: Institut Pertanian Bogor.

Kurniaty RM, Fauzi AM, Chozin MA. 2012. Daya saing PT Benar Flora Utama berdasarkan aktivitas rantai nilai florikultura. Jurnal Manajemen dan Agribisnis 9(3): 146-153.

Leschke J. 2013. Business model mapping: a new to encourage enterpreneural activity and accelerate new venture creation. Journal of Marketing Development and Competitiveness 7(1): 18 26.

Magretta J. 2002. Why business models matter. Harvard Business Review $80: 86-90$

Mansfield GM, Fourie LC. 2004. Strategy and business models-strange bedfellows? A case for convergence and its evolution into strategic architecture. South African Journal of Business Management 35(1): 35-44.

Markides, C. and Charitou, C.D., 2004. Competing with dual business models: a contingency approach. The academy of Management executive 18(3): 22-36.

Mattjik NA. 2011. Membangun usaha tanaman hias dan bunga potong dengan mengaplikasikan bioteknologi khususnya kultur jaringan [tesis]. Bogor: Institut Pertanian Bogor.

McGrath RG. 2010. Business models: a discovery driven approach. Long Range Planning 43(1): 247-261. https://doi.org/10.1016/j.lrp.2009.07.005.

Osterwalder A, Pigneur Y. 2015. Business Model 
Generation (terjemahan). Jakarta: PT Elex Media Komputindo.

Sutedi. 2011. Rancang bangun sistem layanan terpadu tanaman hias berbasis Web. Jurnal Ilmiah ESAI 5(3): $1-14$.

Teece DJ. 2010. Business model, business strategy and inovation. Long Range Planning 43(2-3): 172194. https://doi.org/10.1016/j.1rp.2009.07.003.

Weill P, Malone TW, D'Urso VT, Herman G, Woerner S. 2005. Do Some Business Models Perform Better than Others? A Study of the 1000 Largest US Firms. MIT Center for coordination science working paper. Hlmn 226.

Wisanggara R, Firdaus M, Oktaviani R.. 2018. Daya saing bisnis PT Pesona Daun Mas Asri Berdasarkan aktivitas rantai nilai. Jurnal Aplikasi
Bisnis dan Manajemen (JABM) 4(1): 73. https:// doi.org/10.17358/jabm.4.1.73.

Xia Y, Deng X, Zhou P, Shima K, Teixeira da Silva JA. 2006. The World floriculture industry: dynamics of production and markets. Floriculture, Ornamental and Plant Biotechnology: Advances and Topical Issues IV(1).

Zott C, Amit R. 2010. Business model design: an activity system perspective. LongRange Planning 43(2-3): 216-226. https://doi.org/10.1016/j. 1rp.2009.07.004.

Zott C, Amit R., Massa L. 2011. The business model: recent developments and future research. Journal of management 37(4): 1019-1042. https://doi. org/10.1177/0149206311406265. 